\title{
Zespót antyfosfolipidowy — opis przypadku i przegląd literatury
}

\section{Antiphospholipid syndrome — case report and literature review}

\section{STRESZCZENIE}

Zespół antyfosfolipidowy (APS, antiphospholipid syndrome) jest chorobą autoimmunologiczną charakteryzującą się występowaniem epizodów żylnej choroby zatorowo-zakrzepowej i/lub zakrzepicy tętniczej oraz niepowodzeń położniczych z towarzyszącą obecnością przeciwciał antyfosfolipidowych (APLA, antyphospholipid antibodies). W artykule omówiono obraz choroby oraz zalecenia dotyczą- ce leczenia na podstawie opisu przypadku 43-letniej pacjentki. Przedstawiono również wyniki prac oceniających skuteczność nowych leków przeciwkrzepliwych, tak zwanych non-vitamin $K$ oral anticoagulants (NOACs) u pacjentów z rozpoznaniem APS oraz omówiono wykorzystanie innych leków wpływających pośrednio na procesy zakrzepowe.

Forum Reumatol. 2019, tom 5, nr 3: 137-143

Słowa kluczowe: zespół antyfosfolipidowy, przeciwciała antyfosfolpidowe

\section{WSTEP}

Zespół antyfosfolipidowy (APS, antiphospholipid syndrome) jest chorobą autoimmunologiczną charakteryzującą się występowaniem epizodów żylnej choroby zatorowo-zakrzepowej i/lub zakrzepicy tętniczej oraz niepowodzeń położniczych z towarzyszącą obecnością przeciwciał antyfosfolipidowych (APLA, antyphospholipid antibodies).

Może występować jako pierwotny zespół antyfosfolipidowy (PAPS, primary APS) albo wtórny zespół antyfosfolipidowy (SAPS, secondary $A P S$ ) w przebiegu między innymi chorób układowych tkanki łącznej, zakażeń czy nowotworów.

\section{OPIS PRZYPADKU}

Pacjentka lat 43 przyjęta w lipcu 2018 roku w trybie ostrodyżurowym do Kliniki Endokrynologii z podejrzeniem krwawienia $\mathrm{z}$ przewodu pokarmowego. W dniach poprzedzających hospitalizację wystąpiły wymioty ciemnobrązową treścią i postępujące osłabienie. W wywiadzie w 2014 roku udar niedokrwienny mózgu, wówczas w badaniu MRI ogniska niedokrwienne w płacie czołowym i ciemieniowym, w obrębie tętnicy mózgu środkowej 2 stenotyczne zwężenia oraz jedno krótkoodcinkowe zwężenie w odcinku początkowym tętnicy mózgu przedniej lewej. W maju 2018 roku wystąpiło krytyczne niedokrwienie prawej kończyny dolnej z następową martwicą palców I i II stopy prawej, na podstawie badań obrazowych stwierdzono niedrożność tętnicy udowej powierzchownej oraz obecność skrzepliny w dwóch tętnicach odpowiadających anatomicznie tętnicy głębokiej uda. Wykonano endartektomię tętnicy udowej powierzchownej i sympatektomię lędźwiową, zalecono oczekiwanie na demarkację zmian martwiczych. Poza tym w wywiadzie wieloletni nikotynizm, pacjentka rodziła 6-krotnie, negowała niepowodzenia położnicze.
Adres do korespondencji: lek. Karolina Antkowiak-Piątyszek Prywatna praktyka lekarska e-mail: kar.antkowiak@gmail.com 
Przy przyjęciu zgłaszała osłabienie, bóle kończyn dolnych i bolesne zasinienie paliczków ręki lewej. W trakcie hospitalizacji rozpoznano grzybicze zapalenie przełyku, owrzodzenie żołądka, ostrą niewydolność nerek, niedokrwistość z niedoboru żelaza, nadciśnienie tętnicze, niedoczynność tarczycy. W badaniach obrazowych z istotnych odchyleń cechy uszkodzenia warstwy miąższowej obu nerek, zmniejszenie nerki lewej, w gastroskopii owrzodzenie w antrum żołądka, zmiany zapalne śluzówki dna żołądka, ogniska kandydozy na błonie śluzowej przełyku. W badaniach laboratoryjnych niedokrwistość mikrocytarna z HGB 5,2 g/dl, leukocytoza 16,25 × 10³, CRP $66 \mathrm{mg} / \mathrm{l}$, OB $112 \mathrm{~mm} / \mathrm{h}$, ALT $204 \mathrm{U} / \mathrm{l}$, AST $263 \mathrm{U} / \mathrm{l}$, fibrynogen $444 \mathrm{mg} / \mathrm{dl}$, przeciwciała ANA - miano 1:1280, obecne nukleosomy. Konsultowana reumatologicznie, wysunięto podejrzenie choroby układowej i włączono steroidoterapię (Metypred $16 \mathrm{mg}$ ). Pacjentkę przekazano do Kliniki Reumatologii i Chorób Wewnętrznych.

Przy przyjęciu w badaniu przedmiotowym martwica sucha paliczków dystalnych palców ręki lewej IV i V oraz palców I i II stopy prawej, livedo reticularis na lewym przedramieniu (ryc. 1 i 2). W badaniach laboratoryjnych nadal niedokrwistość mikrocytarna, cechy niewydolności nerek, normalizacja parametrów zapalnych, w badaniach immunologicznych obecne przeciwciała ANA w mianie 1:640 o homogennym typie świecenia, nieobecne przeciwciała ANCA, profil ANA i ANCA

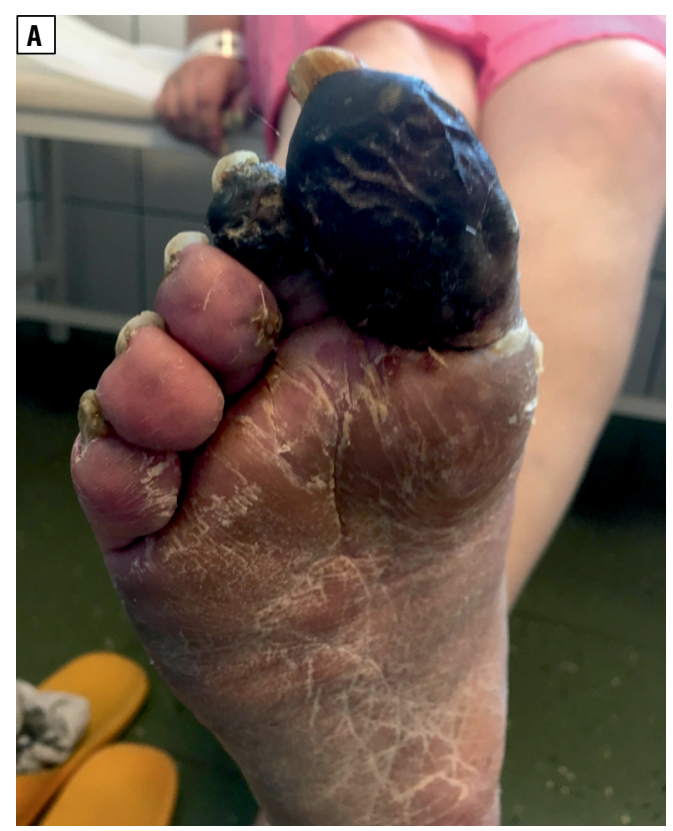

Rycina 1A-B. Stopa prawa — zmiany martwicze ujemny, obecny antykoagulant toczniowy i dodatnie przeciwciała przeciw $\beta_{2}$-glikoproteinie. Na podstawie CT jamy brzusznej i MRI wykluczono proces nowotworowy w jamie brzusznej. Wysunięto podejrzenie zespołu antyfosfolipidowego, w leczeniu zastosowano SoluMedrol $(3 \times 500 \mathrm{mg}$ i.v. $)$, następnie Metypred w dawce $32 \mathrm{mg}$, heparynę drobnocząsteczkową, przetoczono $30 \mathrm{~g}$ immunoglobulin. Konsultowana ortopedycznie, zakwalifikowana do amputacji zmian martwiczych. Zwolniona do domu z zaleceniem kontynuowania steroidoterapii i leczenia antykoagulacyjnego heparyną drobnocząsteczkową.

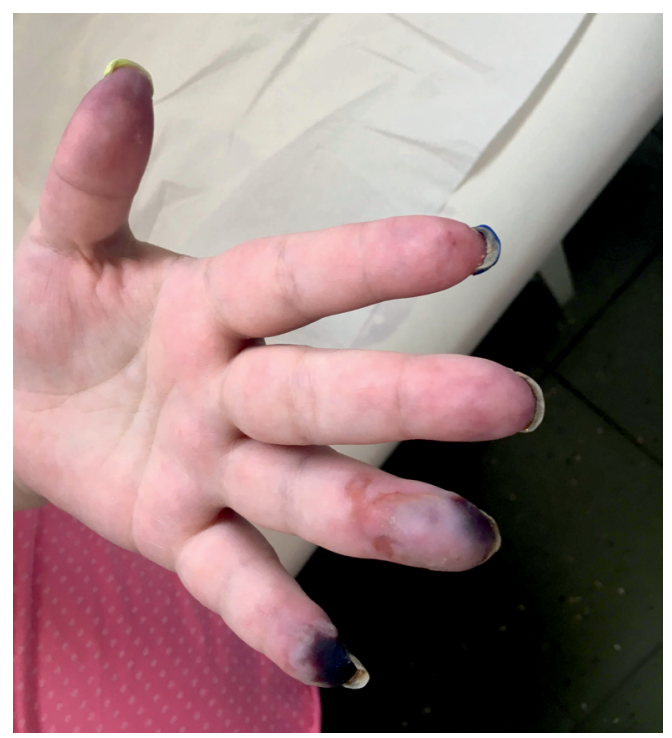

Rycina 2. Ręka lewa — zmiany martwicze

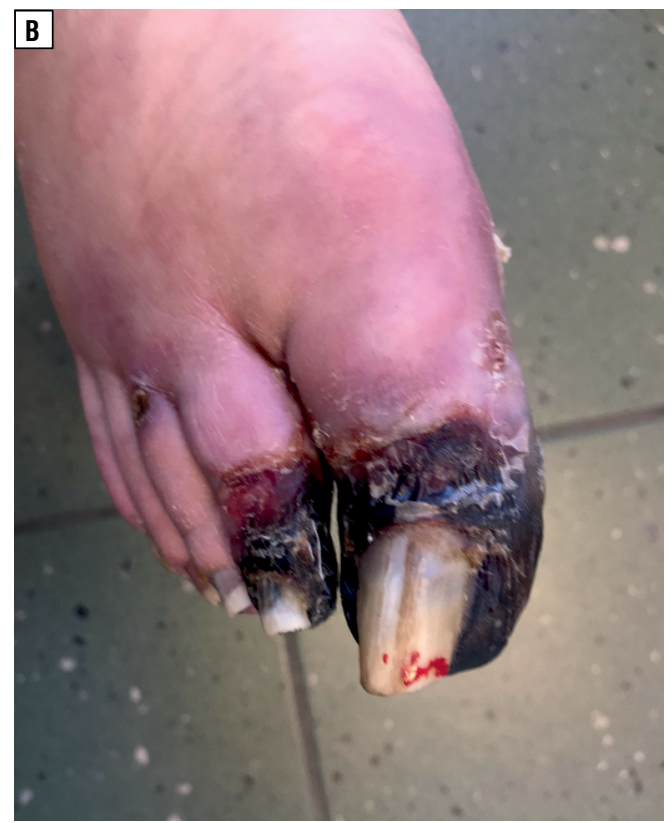




\section{ROZPOZNANIE APS I CAPS}

Zgodnie z obowiązującymi kryteriami (opublikowanymi w 2006 r. przez Miyakis i wsp. [1]) rozpoznanie może być postawione, gdy obecne jest przynajmniej 1 kryterium kliniczne i 1 kryterium laboratoryjne.

Kryteria kliniczne obejmują: zakrzepice żylną, zakrzepicę tętniczą, zakrzepicę drobnych naczyń oraz tak zwane niepowodzenia położnicze definiowane jako: 3 lub więcej samoistne poronienia o niewyjaśnionej przyczynie przed 10 tygodniem ciąży lub/i przedwczesny poród (przed 34 tygodniem ciąży) prawidłowego noworodka lub/i obumarcie prawidłowego morfologicznie płodu od 10 tygodnia ciąży.

Kryteria laboratoryjne obejmują: stwierdzenie występowania w surowicy antykoagulantu toczniowego (LA) i/lub występowania przeciwciał antykardiolipinowych w klasie IgM lub/i IgG w stężeniach średnich lub wysokich (tj. > 40 MPL w przypadku IgM lub > 40 GPL w przypadku IgG albo $>99$ percentyla, metoda ELISA) i/lub przeciwciała przeciwko $\beta_{2}$-glikoproteinie I $\left(\beta_{2}\right.$-GPI) w klasie IgG i/lub IgM w stężeniach $>99$ percentyla. Dodatkowo obowiązują 2 kryteria czasowe: każde z oznaczanych przeciwciał musi być obecne w surowicy minimum 2-krotnie w ciągu $\geq 12$ tygodni oraz między wystąpieniem objawów klinicznych a pojawieniem się APLA nie może minąć mniej niż 12 tygodni i więcej niż 5 lat.

W kryteriach klinicznych nie znalazły się inne objawy kliniczne APS, na przykład hematologiczne (małopłytkowość, niedokrwistość autoimmunohemolityczna, nefrologiczne, siność siatkowata, patologia zastawek. Równoczesna obecność wszystkich 3 rodzajów przeciwciał antyfosfolipidowych wiąże się z gorszym rokowaniem - u tych pacjentów obserwuje się więcej epizodów zakrzepicy [2].

Ponadto ustalono, że na obraz kliniczny choroby ma wpływ na miano przeciwcial (np. ryzyko rozwoju zmian zastawkowych jest wprost proporcjonalne do miana przeciwciał) oraz klasa stwierdzanych przeciwciał (zmiany zastawkowe częściej u osób z przeciwciałami ACA IgG).

\section{SERONEGATYWNY APS}

Od kilku lat pojawiają się też doniesienia opisujące występowanie tak zwanego „seronegatywnego" zespołu antyfosfolipidowego (SNAPS, seronegative APS). Został opisany w 2003 roku [3], obejmuje przypadki pacjen- tów z objawami klinicznymi wysoce sugerującymi APS, jednakże niespełniającymi kryteriów laboratoryjnych. Zgodnie z przeglądem opublikowanych prac [4] szereg kolejnych przeciwciał może być potencjalnie ujętych w przyszłych kryteriach klasyfikacyjnych, między innymi przeciwciała przeciw fosfatydyloetanolaminie (anti-PE), przeciw protrombinie (aPT), przeciw aneksynie $\mathrm{V}$ oraz przeciwciała antykardiolipinowe w klasie IgA lub przeciw $\beta_{2}$-glikoproteinie I w klasie IgA. Co więcej, pojawiły się doniesienia, że u pacjentów z rozpoznanym toczniem układowym przeciwciała aPT IgG są najsilniejszym predyktorem zakrzepicy [5].

Szczególną postacią zespołu antyfosfolipidowego (CAPS, catastrophic antiphospholid syndrome) jest katastrofalny zespół antyfosfolipidowy charakteryzujący się występowaniem gwałtownie postępującej (jednocześnie lub w ciągu tygodnia) niewydolności wielonarządowej (zajęcie $\geq 3$ narządów, układów lub tkanek) z obecnością przeciwciał antyfosfolipidowych i rozpoznaniem zakrzepicy małych naczyń w badaniu histopatologicznym [2]. Pewne rozpoznanie CAPS można postawić po spełnieniu wszystkich powyższych kryteriów, prawdopodobne rozpoznanie - przy spełnieniu $3 \mathrm{z} 4 \mathrm{z}$ dodatkowymi warunkami [6].

\section{OBRAZ KLINICZNY APS}

Obraz kliniczny choroby obejmuje bardzo wiele objawów chorobowych. Oczywiście najczęstszym objawem jest żylna choroba zakrzepowo-zatorowa (ok. 60\% przypadków) oraz rzadziej zakrzepica tętnicza (pod postacią przemijającego niedokrwienia mózgu, udaru mózgu lub zakrzepicy naczyń wieńcowych). W przypadku pierwszego epizodu przebiegiem może nie różnić się od zakrzepicy niezwiązanej z APS. Natomiast uwagę powinna zwrócić zakrzepica w nietypowej lokalizacji (np. żyły kończyn górnych) oraz młody wiek chorych.

Inne objawy to:

— w obrębie układu nerwowego: migrena i inne zespoły bólu głowy, napady padaczkowe, zaburzenia funkcji poznawczych, pląsawica, zespół Guillaina-Barrego, zmiany sugerujące stwardnienie rozsiane, poprzeczne zapalenie rdzenia;

- nadciśnienie tętnicze oraz zmiany zastawkowe, mogące $\mathrm{w}$ konsekwencji prowadzić do niewydolności serca;

- nadciśnienie płucne jako powikłanie choroby zatorowo-zakrzepowej, częściej występu- 
je we wtórnym zespole antyfosfolipidowym z towarzyszącym toczniem układowym;

- zmiany śródmiąższowe nerek, glomerulopatia, zakrzepica żyły nerkowej lub tętnicy nerkowej (częściej u chorych z APS i toczniem układowym), nefropatia APS;

- siność siatkowata;

- zaburzenia psychiczne: zaburzenia lękowe, depresyjne;

- powikłania okulistyczne: najczęściej przemijające zaniewidzenie jednooczne, rzadziej neuropatia nerwu wzrokowego (częściej u chorych $\mathrm{z}$ współistniejącym toczniem układowym), zakrzepica tętnic lub żył siatkówki;

- hematologiczne: małopłytkowość, niedokrwistość autoimmunohemolityczna.

Zakrzepica z obecnością przeciwciał antyfosfolipidowych może być pierwszym objawem nowotworu.

\section{LECZENIE I ZAPOBIEGANIE POWIKKANIOM ZAKRZEPOWYM}

Decyzja o sposobie leczenia i czasie trwania leczenia jest uzależniona od szeregu czynników:

- serologicznego profilu wysokiego lub niskiego ryzyka [7]. Ryzyko wysokie: dodatni LA, potrójnie pozytywne wyniki na obecność APLA (ACA+, LA+, $\beta 2-\mathrm{GPI}+)$, izolowane przetrwałe ACA w mianie od średniego do wysokiego. Ryzyko niskie: izolowane, sporadyczne ACA lub $\beta 2$-GPI w niskim lub średnim mianie;

— umiejscowienia i rozległości zakrzepicy;

- obecności innych niż APS czynników ryzyka zakrzepicy;

- ryzyka powikłań krwotocznych i współwystępowania innych chorób.

Wytyczne dotyczące leczenia zakrzepicy w przebiegu APS zostały przedstawione przez Ruiz-Irastorza w „Lupus” w 2011 roku [8]. Zasadniczo opierają się na leczeniu heparyną drobnocząsteczkową i anagonistami witamina K (VKA). U pacjentów z przejściowym czynnikiem ryzyka zakrzepicy (unieruchomienie, zabieg operacyjny) i obecnością jednego rodzaju APLA leczenie przeciwkrzepliwe można ograniczyć do 3-6 miesięcy. Natomiast u pacjentów wysokiego ryzyka serologicznego lub współistniejąca trombofilią czy inną chorobą autoimmunologiczną leczenie przeciwkrzepliwe z zastosowaniem VKA prowadzi się do końca życia (w okresie ciąży zastępuje się VKA heparynami drobnocząsteczkowymi).
W przypadku nawrotu zakrzepicy tętniczej pomimo właściwego leczenia VKA (INR 2-3) można rozważyć dołączenie leku przeciwpłytkowego (kwas acetylosalicylowy [ASA, acidum acetylsalicylicum]) lub ewentualnie intensyfikować leczenie VKA do uzyskania INR $>3,0$.

W przypadku pacjentów, u których stwierdzono obecność APLA, a nie wystąpiły objawy zespołu antyfosfolipidowego, profilaktyczne leczenie (ASA do $100 \mathrm{mg}$ zaleca się tylko u pacjentów $\mathrm{z}$ obecnością wszystkich 3 rodzajów przeciwciał, u osób z trombofilią i kobiet w ciąży). W okresie unieruchomienia, połogu i okresie okołooperacyjnym zaleca się podawanie heparyny drobnocząsteczkowej w dawkach profilaktycznych.

Szczególne zalecenia terapeutyczne dotyczą pacjentek ciężarnych i okresu połogu [9].

Prowadzenie skutecznego leczenia przeciwzakrzepowego u pacjentów z APS stanowi nadal wyzwanie. Obecność antykoagulantu toczniowego może zaburzać oznaczenie INR, dając wyniki fałszywie zawyżone [10]. To z kolei może prowadzić do nawrotu zakrzepicy. Poza tym VKA wchodzą w interakcję z szeregiem leków, w związku z czym wymagają regularnego monitorowania INR. Natomiast przewlekłe leczenie heparynami drobnocząsteczkowymi wiąże się z ryzykiem wystąpienia małopłytkowości poheparynowej i osteoporozy.

\section{NOAC W LECZENIU APS}

W związku z powyższym od czasu pojawienia się nowych leków przeciwkrzepliwych tak zwanych non-vitamin K oral anticoagulants (NOACs) podejmowane są próby włączenia ich do terapii APS [11]. Leki z grupy NOAC w przeciwieństwie do antagonistów witaminy $\mathrm{K}$ są wybiórczymi inhibitorami czynników krzepnięcia.

Opublikowano kilka prac zawierających opisy przypadków pacjentów leczonych rywaroksabanem i dabigatranem. Wyniki z tych prac są niejednoznaczne. Przykładowo w pracy Signorelli i wsp. opisano przypadki 8 pacjentów leczonych rywaroksabanem. W trakcie terapii u wszystkich pacjentów wystąpił epizod zakrzepicy [12].

Natomiast Son i wsp. przedstawili dane z obserwacji 12 pacjentów leczonych rywaroksabanem [13]. Pacjenci z dodatnim wywiadem w kierunku udaru niedokrwiennego mózgu lub obciążeni wieloma czynnikami ryzyka zakrze- 
picy mieli dodatkowo włączone małe dawki kwasu acetylosalicylowego. W okresie obserwacji (10-16 miesięcy) zarejestrowano tylko 2 przypadki zakrzepicy. U jednego pacjenta w okresie zaostrzenia tocznia układowego rozpoznano zakrzepicę żył głębokich. U kolejnego pacjenta również rozpoznano zakrzepicę żył głębokich, w tym przypadku zakrzepica wystąpiła po urazie kończyny dolnej.

Skuteczność NOAC została też oceniona w randomizowanych badaniach klinicznych. Pierwszym badaniem było badanie Rivaroxaban for Antiphospholipid Antibody Syndrome (RAPS) [14]. Włączono 116 pacjentów, do analizy statystycznej wzięto pod uwagę dane uzyskane od 110 pacjentów (54 pacjentów w ramieniu rywaroksaban, $56 \mathrm{w}$ ramieniu warfaryna). W badaniu w okresie 6 miesięcy nie zarejestrowano żadnego epizodu zakrzepicy, nie obserwowano też istotnych powikłań krwotocznych.

W grudniu 2014 r rozpoczęło się badanie Rivaroxaban in Thrombotic Antiphospholipid Syndrome (TRAPS) oceniające skuteczność leczenia przeciwkrzepliwego rywaroksabanem (20 mg, $15 \mathrm{mg}$ w przypadku pacjentów z klirensem kreatyniny 30-49 ml/min) vs. warfaryna (INR 2,0-3,0). Rywaroksaban jest doustnym inhibitorem czynnika Xa, zarejestrowanym do leczenia VTE i profilaktyki udar mózgu u pacjentów z migotaniem przedsionków. Kryteria włączenia do badania TRAPS obejmowały pacjentów z rozpoznaniem APS (kryteria Miyakis 2006) i obecnością trzech rodzajów APLA (pacjenci „potrójnie pozytywni”). Badanie przerwano przedwcześnie $\mathrm{z}$ powodu częstszego występowania nawrotu zakrzepicy u pacjentów przyjmujących rywaroksaban $(19 \%$ to jest 11 przypadków zakrzepicy vs. 3\%, tj. 2 przypadki zakrzepicy u pacjentów przyjmujących warfarynę). Powikłania krwotoczne wystąpiły u 7\% pacjentów w grupie rywaroksabanu i 3\% pacjentów w grupie warfaryny [15].

Aktualnie nadal trwa badanie Apixaban for the Secondary Prevention of Thromboembolism Among Patients With the Antiphos Pholipid Syndrome (ASTRO-APS). Apiksaban również jest inhibitorem czynnika $\mathrm{Xa}$, ma te same wskazania rejestracyjne co rywaroksaban. Skuteczność leczenia apiksabanem jest porównywana ze skutecznością leczenia warfaryną (INR 2,0-3,0). W trakcie trwania badania zmodyfikowano protokół badania, zwiększono dawkę apiksabanu z 5 mg/dobę do $10 \mathrm{mg} /$ dobę, dołączono nowe kryteria wykluczenia - epizod zakrzepicy tętniczej (w tym udar mózgu) oraz ogniska niedokrwienne w ośrodkowym układzie nerwowym [16].

W związku z powyższymi wynikami leki z grupy NOAC mogą być stosowane w leczeniu żylnej choroby zatorowo-zakrzepowej tylko u pacjentów uczulonych na warfarynę i acenocumarol lub przy braku możliwości utrzymania terapeutycznych wartości INR. Nadal podstawowymi lekami przeciwzakrzepowymi pozostaje heparyna drobnocząsteczkowa i VKA, a w przypadku położniczego APS heparyna i małe dawki kwasu aceetylocysteinowego.

\section{INNE MOŻLIWOŚCI TERAPEUTYCZNE}

W związku z bardzo złożoną patogenezą APS obejmującą aktywację układu dopełniacza, układu krzepnięcia i płytek, aktywację endotelium [17] w leczeniu zespołu antyfosfolipidowego brane są też pod uwagę leki wpływające pośrednio na procesy zakrzepowe.

Hydroksychlorochina pierwotnie traktowana jako lek przeciwmalaryczny, wykazuje działanie immunomodulujące i przeciwzakrzepowe. Zmniejsza też ryzyko powikłań sercowo-naczyniowych w przebiegu APS. Mechanizm działania obejmuje między innymi hamowanie aktywację płytek wywołaną działaniem APL, redukuje efekt prozakrzepowych przeciwciał przeciw aneksynie $\mathrm{V}$, zmniejsza negatywny wpływ APL na różnicowanie trofoblastu [8, 18, 19]. Szereg prac sugeruje, że stosowanie hydroksychlorochiny przez ciężarne pacjentki poprawia rokowanie co do przebiegu ciąży [20]. Trwa badanie HYPATIA mające potwierdzić ten korzystny wpływ [21]. Hydroksychlorochina jest rekomendowana w postępowaniu terapeutycznym u pacjentów $\mathrm{z}$ toczniem układowym i towarzyszącym zespołem antyfosfolipidowym [8]. Podkreśla się korzystny profil bezpieczeństwa tego leku i brak ryzyka krwawienia.

Przeciwciała antyfosfolipidowe biora też udział w aktywacji szlaku mTOR, prowadząc do przerostu błony środkowej naczynia, a w konsekwencji do waskulopatii będącej jedną z przyczyn zamykania naczyń tętniczych w nerkach [22]. W leczeniu tej postaci nefropatii APS rozważa się włączenie rapamycyny (sirolimus) będącej inhibitorem mTOR.

Inna potencjalną drogą terapeutyczną jest blokowanie układu dopełniacza poprzez stosowanie ekulizumabu. Ekulizumab (soliris) jest przeciwciałem monoklonalnym skierowanym przeciw składowej C5 dopełniacza, hamuje syntezę kompleksu atakującego błonę 
C5b-9 (MAC, membrane attack complex). Jest zarejestrowany w Polsce w leczeniu atypowego zespołu hemolityczno-mocznicowego (aHUS, haemolytic-uraemic syndrome), opornej na leczenie uogólnionej miastenii rzekomoporaźnej (gMG, myasthenia gravis) oraz nocnej napadowej hemoglobinurii (PHN, paroxysmal nocturnal hemoglobinuria). Opisano zastosowanie tego leku w leczeniu katastrofalnego zespołu antyfosfolipidowego [23] oraz jako skuteczną profilaktykę waskulopatii w przeszczepionej nerce u pacjentów z nefropatią APS [24].

W leczeniu CAPS stosowano również dobrze znany w reumatologii rytuksymab. Rytuksymab jest białkiem monoklonalnym skierowanym przeciw antygenowi CD-20 pre-limfocytów B i limfocytów B. Skuteczność leku trudno ocenić, bowiem analiza opiera się na danych z rejestru przypadków CAPS, rytuksymab stanowił jeden $\mathrm{z}$ elementów leczenia obok steroidoterapii, wlewów immunoglobulin, leczenia przeciwzakrzepowego, leczenia cyclofosfamidem czy wreszcie plazmaferezy. Jednakże w związku z trudnościami w przeprowadzeniu randomizowanego badania $\mathrm{w}$ tym wskazaniu, wydaje się, że dotychczasowe doświadczenia z tym lekiem są obiecujące [25, 26].

Podobne ograniczenia dotyczą cyclofosfamidu, niemniej posiadamy dane $z$ analizy stosowania cyclofosfamidu w CAPS [27].
U pacjentów z CAPS i toczniem układowym stosowanie cyclofosfamidu skutkowało niższą śmiertelnością w przebiegu CAPS. Natomiast u pacjentów niechorujących na toczeń układowy, leczenie CAPS cyclofosfamidem wiązało się z większą śmiertelnością, ale autorzy analizy zwracają uwagę, że dotyczyła ona chorych z cięższymi postaciami CAPS. W związku z heterogennością grup trudno wyciągać jednoznaczne wnioski.

\section{PODSUMOWANIE}

Skuteczne leczenie zespołu antyfosfolipidowego nadal stanowi wyzwanie. Szansę należy upatrywać w leczeniu opartym na mechanizmie leżącym u podstaw procesu zakrzepowego, bowiem ryzyko ponownego epizodu zakrzepicy jest duże. Szczególnie dotyczy to przypadków zakrzepicy tętniczej. Według analizy [27] wieloośrodkowej bazy danych pacjentów (Antiphospholipid Syndrome Alliance for Clinical Trials and International Networking) 20\% leczonych pacjentów z zakrzepicą tętniczą w wywiadzie będzie miało nawrót zakrzepicy w ciągu 3,4 roku (w przypadku terapii przeciwpłytkowej), 7,3 roku (w przypadku terapii antykoagulacyjnej) i 16,3 roku (w przypadku terapii łączonej przeciwpłytkowej i antykoagulacyjnej).

\section{ABSTRACT}

Antiphospholipid syndrome (APS) is an autoimmune disease defined by the occurrence of arterial/venous thrombotic events and/or pregnancy loss with persistent positive antiphospholipid antibodies (APLA). This article focuses on the current therapy recommendations, including the role of novel oral anticoagulants (NOACS) and non-antithrombotic-based treatment.

Forum Reumatol. 2019, tom 5, nr 3: 137-143

Key words: antiphospholipid syndrome; APS; antiphospholipid antibodies; APLA; NOACs

\section{Piśmiennictwo}

1. Miyakis S, Lockshin MD, Atsumi T, et al. International consensus statement on an update of the classification criteria for definite antiphospholipid syndrome (APS). J Thromb Haemost. 2006; 4(2): 295-306, doi: 10.1111/j.1538-7836.2006.01753.x, indexed in Pubmed: 16420554.

2. Hernández-Molina G, Espericueta-Arriola G, Cabral AR. The role of lupus anticoagulant and triple marker positivity as risk factors for rethrombosis in patients with primary antiphospholipid syndrome. Clin Exp Rheumatol. 2013; 31(3): 382-388, indexed in Pubmed: 23305633.

3. Hughes GR, Khamasta MA, et al. Seronegative antiphospholipid syndrome. Ann Rheum Dis. 2003; 62(12): 1127.

4. Nayfe R, Uthman I, Aoun J, et al. Seronegative antiphospholipid syndrome. Rheumatology (Oxford). 2013; 52(8):
1358-1367, doi: 10.1093/rheumatology/ket126, indexed in Pubmed: 23502076.

5. Bizzaro N, Ghirardello A, Zampieri S, et al. Anti-prothrombin antibodies predict thrombosis in patients with systemic lupus erythematosus: a 15-year longitudinal study. J Thromb Haemost. 2007; 5(6): 1158-1164, doi: 10.1111/j.1538-7836.2007.02532.x, indexed in Pubmed: 17388963

6. Asherson RA, Cervera R, de Gr, et al. Catastrophic antiphospholipid syndrome: international consensus statement on classification criteria and treatment guidelines, Lupus. 2003; 12(7): 530-4.

7. Simchen MJ, Dulitzki M, Rofe G, et al. High positive antibody titers and adverse pregnancy outcome in women 
with antiphospholipid syndrome. Acta Obstet Gynecol Scand. 2011; 90(12): 1428-1433, doi: 10.1111/j.1600-0412.2011.01236.x, indexed in Pubmed: 21729009.

8. Ruiz-Irastorza G, Cuadrado MJ, Ruiz-Arruza I, et al. Evidence-based recommendations for the prevention and long-term management of thrombosis in antiphospholipid antibody-positive patients: Report of a Task Force at the 13th International Congress on Antiphospholipid Antibodies. Lupus. 2011; 20(2): 206-18.

9. Lockwood Ch, Lockshin M, Management of antiphospholipid syndrome in pregnant and postpartum women. 2017. www.uptodate.com.

10. Cohen $\mathrm{H}$, Machin SJ. Antithrombotic treatment failures in antiphospholipid syndrome: the new anticoagulants? Lupus. 2010; 19(4): 486-491, doi: 10.1177/0961203310361355, indexed in Pubmed: 20353992.

11. White CW, Thomason AR, Boyd K. Role of Novel Oral Anticoagulants in the Treatment of Antiphospholipid Syndrome. Hosp Pharm. 2016; 51(9): 759-767, doi: 10.1310/hpj5109-759, indexed in Pubmed: 27803506.

12. Signorelli $F$, Nogueira $F$, Domingues $V$, et al. Thrombotic events in patients with antiphospholipid syndrome treated with rivaroxaban: a series of eight cases. Clin Rheumatol. 2016; 35(3): 801-805, doi: 10.1007/s10067-015-3030-y, indexed in Pubmed: 26219490.

13. Son M, Wypasek E, Celinska-Lowenhoff M, et al. The use of rivaroxaban in patients with antiphospholipid syndrome: A series of 12 cases. Thromb Res. 2015; 135(5): 10351036, doi: 10.1016/j.thromres.2015.01.028, indexed in Pubmed: 25669601

14. Cohen H, Hunt BJ, Efthymiou M, et al. Rivaroxaban versus warfarin to treat patients with thrombotic antiphospholipid syndrome, with or without systemic lupus erythematosus (RAPS): a randomised, controlled, open-label, phase $2 / 3$, non-inferiority trial, Lancet 2016, Sep. ; 3(9): e426-36.

15. Pengo V, Denas G, Zopperallo G, et al. Rivaroxaban vs warfarin in high-risk patients with antiphospholipid syndrome, 2018. Blood. 2018; 132(13): 1365-1371, doi: 10.1182/blood-2018-04-848333, indexed in Pubmed: 30002145 .

16. Woller SC, Stevens SM, Kaplan DA et al. Protocol Modification of Apixaban for the Secondary Prevention of Thrombosis Among Patients Wiih Antiphospholipid Syndrome Study. https://journals.sagepub.com.

17. Corban MT, Duarte-Garcia A, McBane RD, et al. Antiphospholipid Syndrome: Role of Vascular Endothelial Cells and Implications for Risk Stratification and Targeted Therapeutics. J Am Coll Cardiol. 2017; 69(18): 2317-2330, doi: 10.1016/j.jacc.2017.02.058, indexed in Pubmed: 28473138 .
18. Rand JH, Wu XX, Quinn AS, et al. Hydroxychloroquine protects the annexin $A 5$ anticoagulant shield from disruption by antiphospholipid antibodies: evidence for a novel effect for an old antimalarial drug. Blood. 2010; 115(11): 22922299, doi: 10.1182/blood-2009-04-213520, indexed in Pubmed: 19965621.

19. Schmidt-Tanguy A, Voswinkel J, Henrion D, et al. Antithrombotic effects of hydroxychloroquine in primary antiphospholipid syndrome patients. J Thromb Haemost. 2013; 11(10): 1927-1929, doi: 10.1111/jth.12363, indexed in Pubmed: 23902281.

20. De Carolis S, Botta A, Salvi S, et al. Is there any role for the hydroxychloroquine (HCQ) in refractory obstetrical antiphospholipid syndrome (APS) treatment? Autoimmun Rev. 2015; 14(9): 760-762, doi: 10.1016/j.autrev.2015.04.010, indexed in Pubmed: 25936295.

21. AnTIphospholipid Antibodies (HYPATIA) Protocol: A Multinational Randomized Controlled Trial of Hydroxychloroquine versus Placebo in Addition to Standard Treatment in Pregnant Women with Antiphospholipid Syndrome or Antibodies, EudraCT number 2016-002256-25. https://www. clinicaltrialsregister.eu.

22. Canaud G, Bienaimé F, Tabarin F, et al. Inhibition of the mTORC pathway in the antiphospholipid syndrome. N Engl J Med. 2014; 371(4): 303-312, doi: 10.1056/NEJMoa1312890, indexed in Pubmed: 25054716.

23. Strakhan M, Hurtado-Sbordoni M,, Galeas N et al. Case Report 36-Year-Old Female with Catastrophic Antiphospholipid Syndrome Treated with Eculizumab: A Case Report and Review of Literature, Case Reports in Hematology, Volume 2014, Article ID 704371.

24. Lonze BE, Zachary AA, Magro CM, et al. Eculizumab prevents recurrent antiphospholipid antibody syndrome and enables successful renal transplantation. Am J Transplant. 2014; 14(2): 459-465, doi: 10.1111/ajt.12540, indexed in Pubmed: 24400968.

25. Rodríguez-Pintó I, Cervera R, Espinosa G. Rituximab and its therapeutic potential in catastrophic antiphospolipid syndrome. Ther Adv Musculoskelet Dis. 2015; 7(1): 26-30, doi: $10.1177 / 1759720 \times 14554793$, indexed in Pubmed: 25649844.

26. KazzazNM, McCuneWJ, KnightJS. Treatment of catastrophic antiphospholipid syndrome. Curr Opin Rheumatol. 2016; 28(3): 218-227, doi: 10.1097/BOR.0000000000000269, indexed in Pubmed: 26927441.

27. Jackson WG, Oromendia C, Unlu 0, et al. Antiphospholipid Syndrome Alliance for Clinical Trials and International Networking. Recurrent thrombosis in patients with antiphospholipid antibodies and arterial thrombosis on antithrombotic therapy. Blood Adv. 2017; 1(25): 2320-2324, doi: 10.1182/bloodadvances.2017008185, indexed in Pubmed: 29296881. 